\title{
Floodplain Characteristics of the Mekong Delta in Cambodia
}

\author{
OKETANI Seiichiro*, HARUYAMA Shigeko**, and Sotham SIENG*** \\ * Graduate Student, Graduate School of Frontier Sciences, University of Tokyo, \\ Kashiwa 277-8563, Japan \\ ** Graduate School of Frontier Sciences, University of Tokyo, \\ Kashiwa 277-8563, Japan \\ *** Department of Geology, GDMR, MIME, Phnom Penh, Cambodia
}

\begin{abstract}
The purpose of this study was to examine the floodplain characteristics of the inner Mekong Delta, on the lower part of the Mekong River in Cambodia. Previous works have not investigated the floodplain characteristics of the fluvial dominated area of the Mekong Delta. To grasp the morphology of the study area, we first constructed topographical profiles from hydrologic maps and Space Shuttle Radar Topography Mission 3 data. Then, focusing on the morphology of the floodplain, we produced a land classification map based on aerial photo interpretation and field survey and identified the morphological structures of the study area. We classified the delta landforms as natural levee, back marsh, abandoned channel, alluvial terrace, swamp, point bar, and artificial landforms, including colmatages. We identified four floodplain zones. Zone A floodplains, along the upper part of the Mekong River, have cut-off point bar patterns. Those in zone B, along the lower part of the Mekong River, are linear, and develop back marsh widely. In zone $\mathrm{C}$, along the Bassac River, the floodplains follow the river meanders, and are characterized by unevenly distributed artificial colmatages. Floodplains in zone D, along the Tonle Sap River, which has an extremely low gradient, display a unique geomorphology caused by seasonally reversed river flows.
\end{abstract}

Key words: land classification, the Mekong River, fluvial geomorphology

\section{Introduction}

Previous studies of Holocene sea-level change in the Vietnamese coastal area have revealed that the highest Holocene sea level was $+2.5 \mathrm{~m}$ at $6 \mathrm{ka}$ (Lap et al. 2000). Lee (2001) showed that the climate in this region changed to a monsoon climate at around $8500 \mathrm{yBP}$ by analyzing lake sediment samples from Cambodia. Lap et al. (2000), Ta et al. (2002), and Tanabe et al. (2003) showed that in Vietnam, the Mekong River delta prograded from 3000 to $2000 \mathrm{yBP}$, by analyzing whole-core samples and constructing a land classification map of southern Vietnam. Takaya (1974, 1975) and Furukawa and Takaya (1987) categorized the landforms of Vietnam and Cambodia according to agricultural use patterns. Tamura et al. (2005) proposed that the area 20 km southeast of Phnom Penh (PP), Cambodia, was influenced primarily by fluvial processes be- fore $9.0 \mathrm{ka}$, then became a tide-dominated area, and finally became a saline marsh during 9.0-7.0 ka. The Ministry of Public Works and Transport, Kingdom of Cambodia, and Japan International Cooperation Agency (1999) have constructed a map of the geology and geomorphology of Cambodia, the Cambodia Reconnaissance Survey Digital Data (CRSD map). Kubo (2003, 2006) also made a geomorphological map covering $2,500 \mathrm{~km}^{2}$ of the area around PP, focusing on flood characteristics.

However, the floodplain characteristics of the Upper Mekong River Delta, in Cambodia, have rarely been studied and the Mekong River formation process including its tributaries also has not been studied. Therefore, this study examined the floodplain characteristics of the inner delta, focusing on those along the Mekong River (MR). The river's gradient was determined by using data from hydrographic atlases of the Mekong River (Mekong River Commission and Ministry of 
Transport of Vietnam 1998, Mekong River Commission, and Ministry of Public Work and Transport of Cambodia 1999), while relief structures were identified from Space Shuttle Radar Topography Mission 3 (SRTM-3) data, and a land classification map was produced.

\section{Geographical Setting}

The study area (Figure 1) comprises the floodplains along the Mekong River from Kampong Cham (K. Cham) to the Cambodia-Vietnam border ( $\mathrm{C}-\mathrm{V}$ border), along the Bassac River from $\mathrm{PP}$ to $\mathrm{C}-\mathrm{V}$ border, and along the Tonle Sap River. These three rivers join near PP.

The Mekong River is $4,425 \mathrm{~km}$ long, and it drains an area of about $800,000 \mathrm{~km}^{2}$. The lower part of its basin is under a tropical monsoon climate characterized by alternating dry and rainy seasons. As a result, the Mekong River discharge varies greatly over the course of the year. At PP, the water level varies annually by up to $10 \mathrm{~m}$. The upper Mekong River in Laos flows across the Korat Plateau, which has a very small gradient. Hence, coarse-grained sediments are rarely transported to the lower river (Haruyama and Ohya 1990). Downstream of the Korat Plateau, the river flows with a swift current and then over Khone Falls. Downstream of the falls, the gradient again becomes extremely small in the area of the Mekong River Delta. The CRSD map (The Ministry of Public Works and Transport, Kingdom of Cambodia, and Japan International Cooperation Agency 1999) shows that basaltic hills constrict the river around K. Cham.

The Tonle Sap River, a tributary of the Mekong River, is about $130 \mathrm{~km}$ long. Reverse flow from the Mekong River up the Tonle Sap River is thought to have started at about 5000 to 5750 yBP (Okawara and Tsukawaki 2002; Penny et al. 2005). Tonle Sap Lake, which lies northwest of the study area, experiences an annual water level change of about $9 \mathrm{~m}$ as a result of the reverse flow from the Mekong River (Haruyama and Ohya 1990). The sedimentation rate in Tonle Sap Lake has been estimated to be about $0.1 \mathrm{~m} / \mathrm{ka}$ during the last 5000 years (Okawara and Tsukawaki 2002). The Bassac River diverges from the Mekong River near PP, and then flows into Vietnam. Many artificial dikes

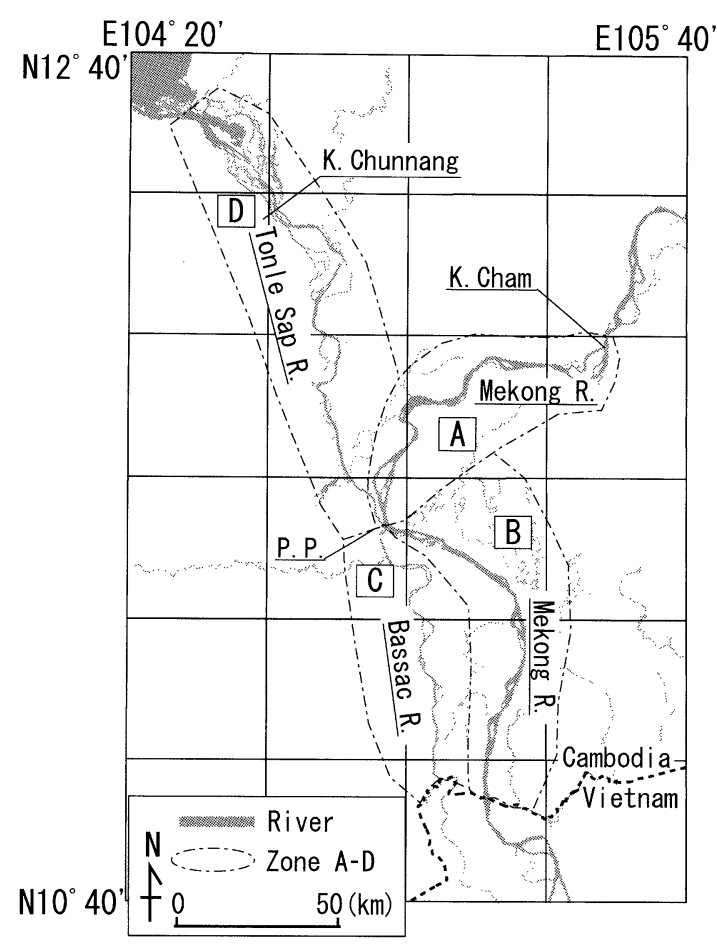

Figure 1. Study area.

Zones A-D are classified according to their floodplain characteristics.

have been constructed for irrigation systems called "colmatages" along the Bassac River (Toda et al. 2005; Kubo 2006). Colmatages have a ditch which irrigates the soil from the main channel to its back marsh during high discharge. Therefore, the deposition induced by irrigation accumulates like small mounds.

The CRSD map (the Ministry of Public Works and Transport, Kingdom of Cambodia, and Japan International Cooperation Agency, 1999) (Figure 2) also shows that alluvial plains have developed from $\mathrm{K}$. Cham to the $\mathrm{C}-\mathrm{V}$ border, and pediments and terraces lie to the west of the study area. The surface geology of the Mekong River floodplains comprise alluvial plain deposits and organic deposits (swamps). Upstream of K. Cham, the flow of the Mekong River is constricted by basaltic hills. A granite monadnock rises near the Tonle Sap River, south of Tonle Sap Lake and adjacent to Kampong Chunnang (K. Chunnang). Kubo (2006) identified terraces and fans to the west of the Tonle Sap River, and higher terraces on both the western and eastern sides. Kubo 


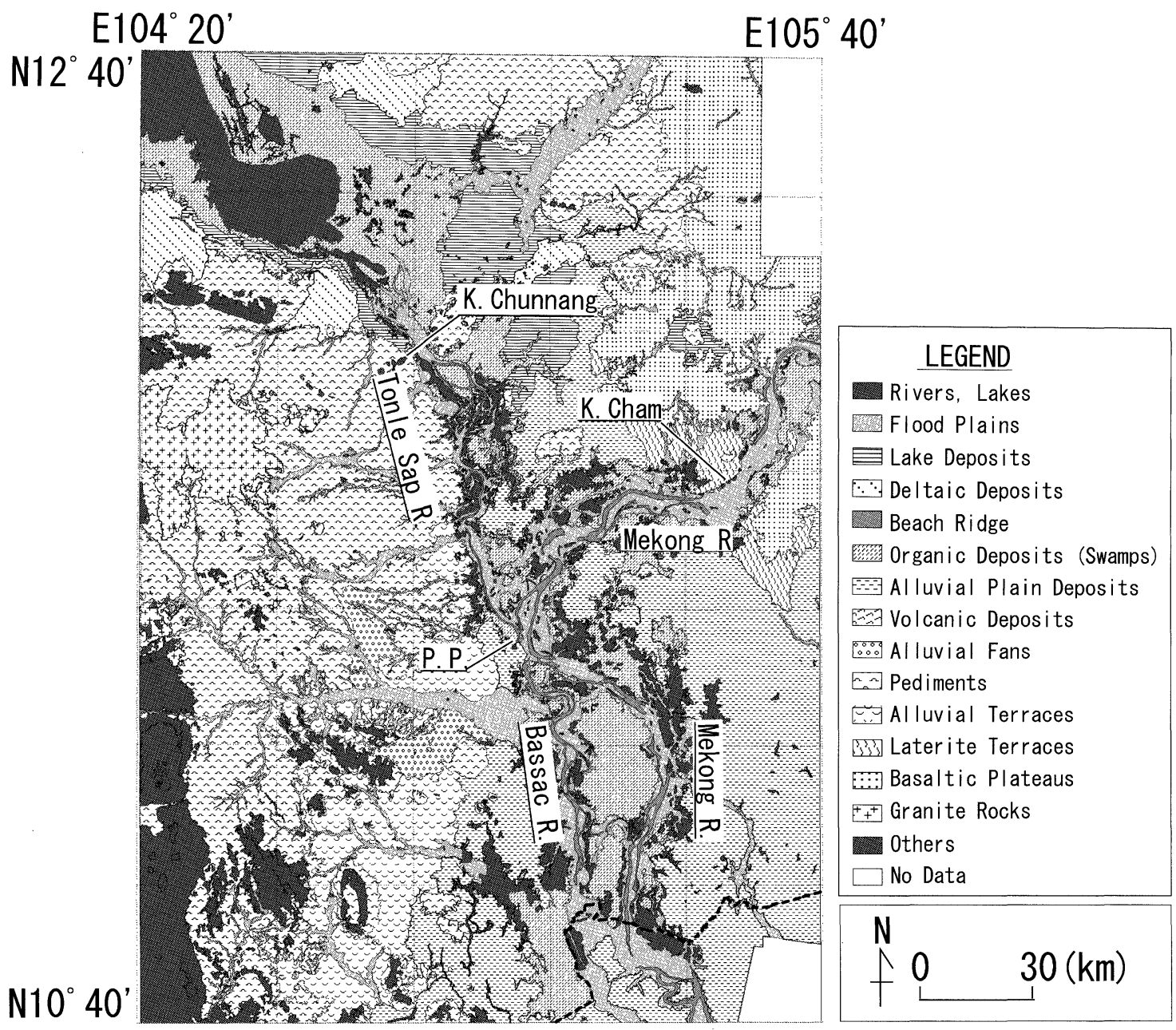

Figure 2. Map of the geology and geomorphology in the study area, constructed using CRSD.

(The Ministry of Public Works and Transport, Kingdom of Cambodia, and Japan International Cooperation Agency, 1999).

(2006) also classified the floodplains of this region into three areas, the Mekong River, Bassac River, and Tonle Sap River floodplains.

\section{Methods}

\section{River channel analysis}

The longitudinal profile of the bed of the Mekong River from the river mouth to $700 \mathrm{~km}$ upstream was determined from Hydrographic Atlas of the Mekong River (Mekong River Commission and Ministry of Transport of Vietnam 1998; Mekong River Commission and Ministry of Public Work and Transport of Cambodia 1999), by plotting the river's depth at $1 \mathrm{~km}$ intervals
(Figure 3). Meander geometry is expressed in terms of sinuosity and mean channel width (Table 1).

\section{Relief analysis}

Remote sensing data are suitable for grasping the characteristics of a wide area. Because of their high resolution, SRTM-3 data are particularly suitable for analyzing topographical profiles. Utilizing TNTmips Version 6.9 or GIS software, we analyzed the topography of the Mekong River Delta from SRTM-3 data.

SRTM-3 data include some topographical errors caused by water areas. To eliminate these errors, the data were first filtered with an 


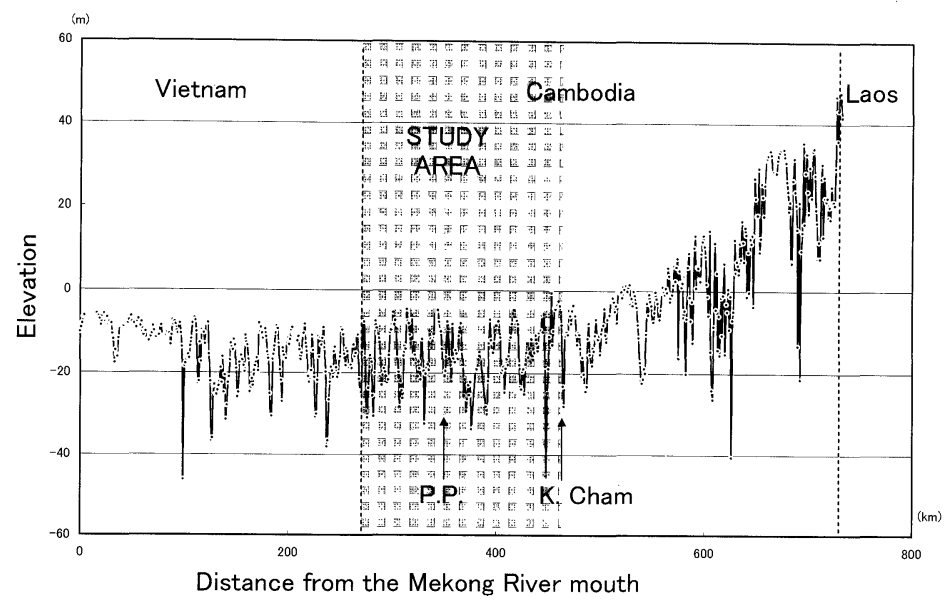

Figure 3. Longitudinal riverbed profile of the Mekong River from $800 \mathrm{~km}$ upstream to its mouth.

This figure was constructed using riverbed elevation at 1-km intervals obtained from hydrologic atlases (Mekong River Commission and Ministry of Transport of Vietnam 1998 and Mekong River Commission, and Ministry of Public Work and Transport of Cambodia 1999). The Mekong River has two segments that differ in gradient.

Olympic 3 by 3 pixel filter (Russ 1995). In topographical sections of the study area, the following errors can not be ignored, because the altitudinal range of the study area is 0 to $20 \mathrm{~m}$. The data error appears as a series of stripes (Bernhard et al. 2003), containing an altitudinal error of $3-5 \mathrm{~m}$, which are especially visible in the lower part of the Mekong River Delta. The error stripes are tilted $30^{\circ}$ WSW-ENE (Andy et al. 2004). Therefore, the relief structures were made by sampling the data stream at 2-minute intervals along the error stripes lines to avoid topographical noise (Figure 4).

\section{Landform classification}

The landforms were mapped to show the floodplain characteristics in the study area. Features shown on the map include natural levees, back marsh I, back marsh II, abandoned channels, valley bottom plain and artificial area after Ohya et al. (2002), as well as swampy areas, alluvial terraces, floodplain bars and swales as point bars, monadnock and mountains. Furthermore, colmatages (artificial irrigation ditch and around) are shown, because they are very widely distributed and connect natural terrains.

Panchromatic aerial photos taken by FINMAP, mostly in December 1992 and February 1993 belonging to the Ministry of Public Works and Transport, Kingdom of Cambodia, were used.
The scale of these aerial photos is $1 / 20,000$. The surface geology was also observed in the field during four periods, August to September 2004, December 2004 to January 2005, August to September 2005, and December 2005, because the flooded areas change dramatically between the dry and rainy seasons. In the field survey, we observed sediment facies in outcrops $2-5 \mathrm{~m}$ deep, and we also observed river bank exposures, because in the dry season, the tops of the river banks are several meters above the water level. In addition, surface geological samples were collected with a hand auger from typical geological units, at points with minimal artificial disturbance. These samples were about $20 \mathrm{~mm}$ in diameter and about $1.4 \mathrm{~m}$ long.

\section{Area classification}

The geomorphological classification map suggests that characteristics of the floodplains differed among four zones (Figure 1): zone A comprised the floodplains along the Mekong River from $\mathrm{K}$. Cham to $20 \mathrm{~km}$ downstream of PP, zone $\mathrm{B}$ comprised those along the Mekong River from $20 \mathrm{~km}$ downstream of PP to $\mathrm{C}-\mathrm{V}$ border, floodplains in zone $\mathrm{C}$ occurred along the Bassac River, and those in zone D were along the Tonle Sap River. Furthermore, the terraces above the floodplains were also categorized. 


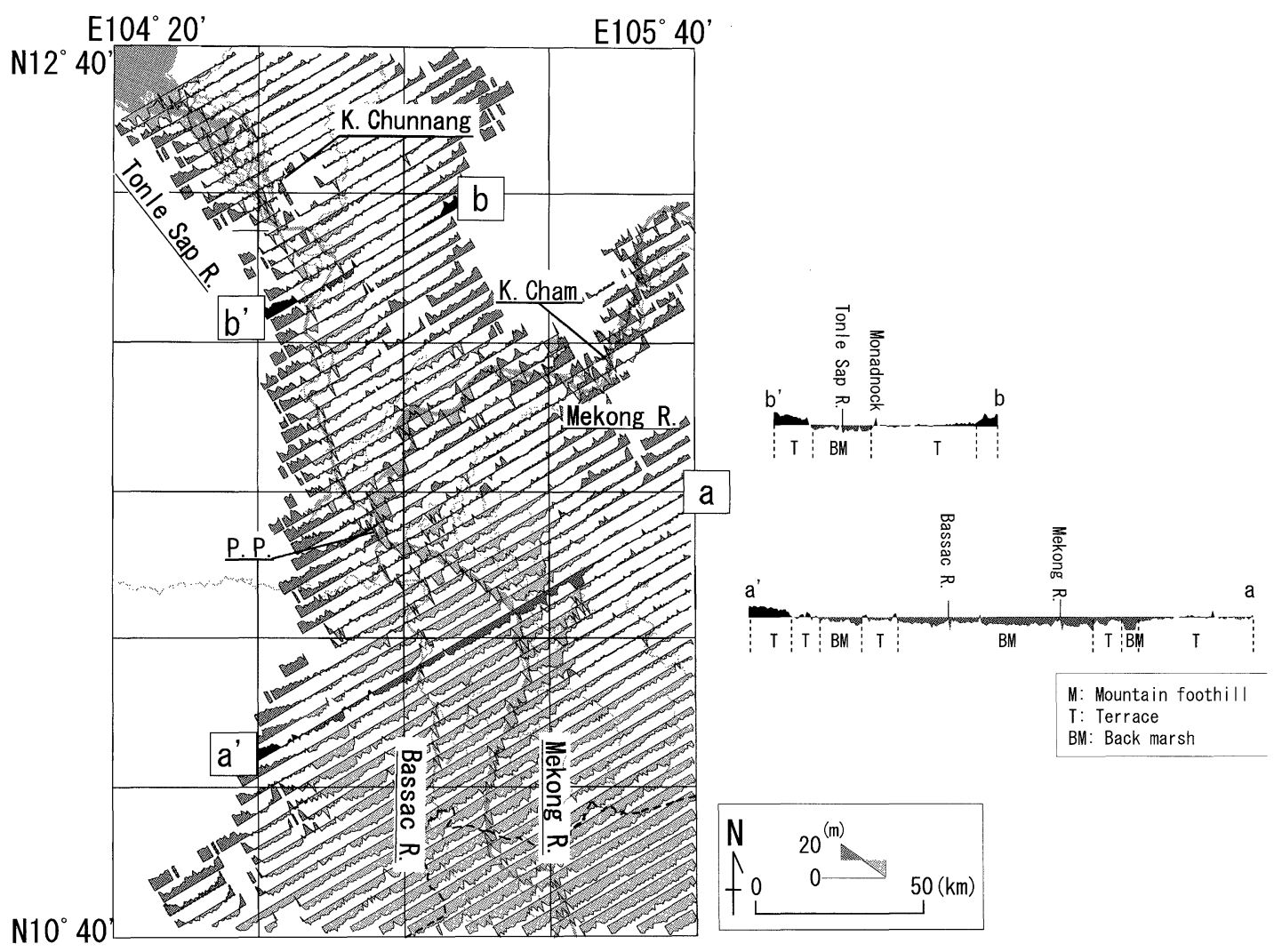

Figure 4. Topographic relief sections.

The data stream was sampled at 2 minute intervals, using SRTM-3 data. The datum line of each profile is $10 \mathrm{~m}$ a.s.l. Dark gray shading above the line indicates elevations from 10 to $20 \mathrm{~m}$ a.s.l., and light gray shading below the line indicates elevations from 0 to $10 \mathrm{~m}$ a.s.l. Therefore, it is easy to distinguish between mountainous areas, terraces, and floodplains.

\section{Results}

\section{Channel characteristics}

The Mekong River from the river mouth to $750 \mathrm{~km}$ upstream consists of two segments (Figure 3). The lower segment, from the river mouth to K. Cham, which is $450 \mathrm{~km}$ upstream, has a riverbed gradient of $0.10 / 10,000$. All of the study area is included in this segment. The upper segment, from 450 to $750 \mathrm{~km}$ upstream of the river mouth, has a gradient of $1.33 / 10,000$. Channel characteristics in the four zones are as follows (summarized in Table 1).

Zone A: The Mekong River flows from $\mathrm{K}$. Cham to PP between terraces. The river is mostly meandering in this zone. Average sinuosity (channel length/wavelength) is 1.24. The average wavelength is $10.7 \mathrm{~km}$, and the average channel width is $1.64 \mathrm{~km}$.

Zone B: The Mekong River channel becomes relatively straight from a point $20 \mathrm{~km}$ downstream of $\mathrm{PP}$ to the $\mathrm{C}-\mathrm{V}$ border. This zone has many longitudinal bars: at $21-23 \mathrm{~km}, 24-25 \mathrm{~km}$, $33-37 \mathrm{~km}, 45-50 \mathrm{~km}, 51-55 \mathrm{~km}, 64-67 \mathrm{~km}, 71-73$ $\mathrm{km}$ and $77-83 \mathrm{~km}$ downstream of PP.

Zone C: The Bassac River is a meandering river. At each meander, the channel divides into two flow paths by long longitudinal bars. Average sinuosity is 1.45 (average wavelength, $6.3 \mathrm{~km}$; average width, $0.46 \mathrm{~km}$ ).

Zone D: The Tonle Sap River diverges and converges several times. From PP to a point $40 \mathrm{~km}$ upstream, the channel is linear except at the confluence of a tributary at $15 \mathrm{~km}$ above PP. From 40 to $105 \mathrm{~km}$ upstream from PP, the river channel is adjacent to a granite monadnock near $\mathrm{K}$. Chunnang in the north, terraces occur west 


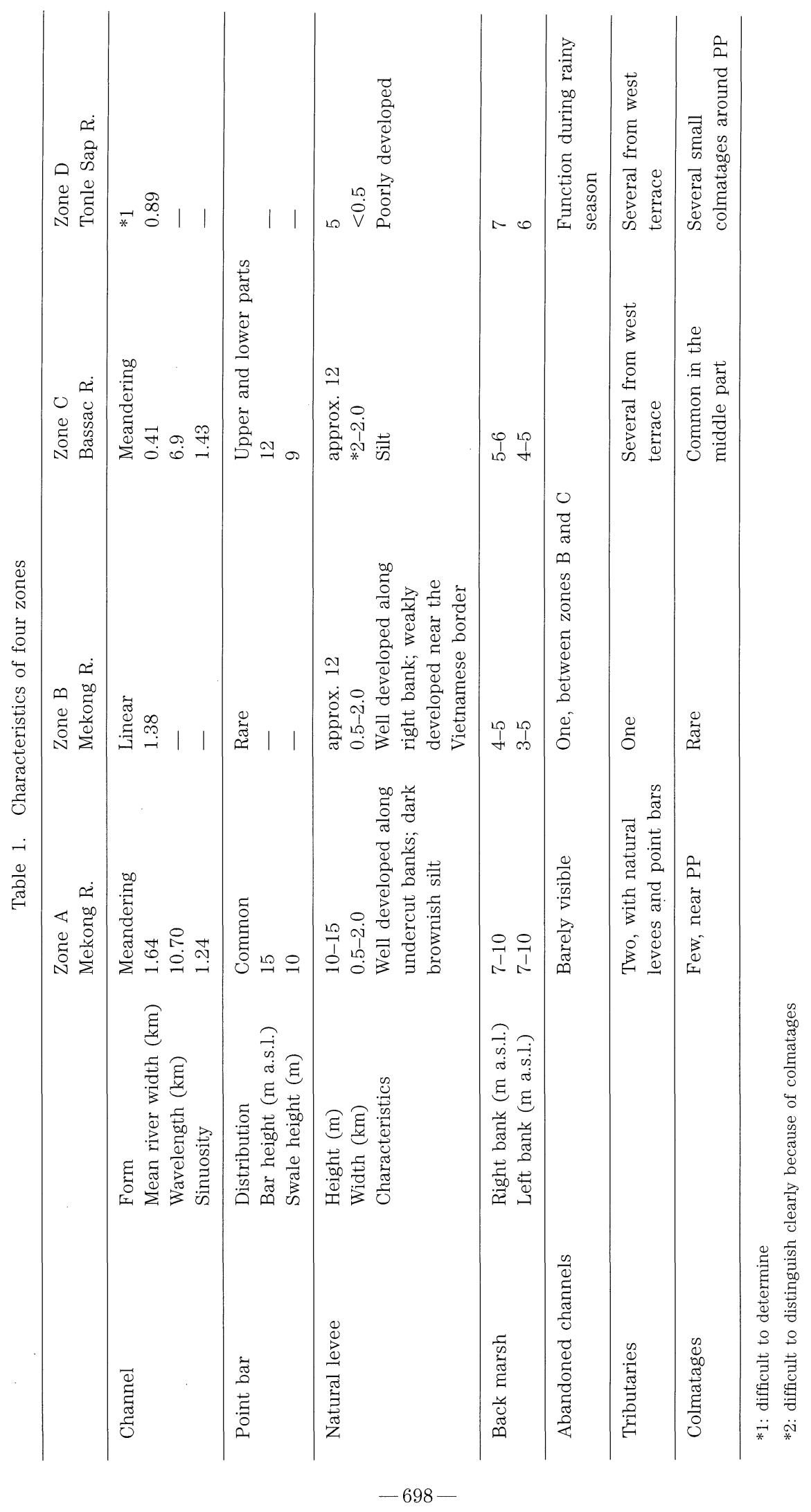




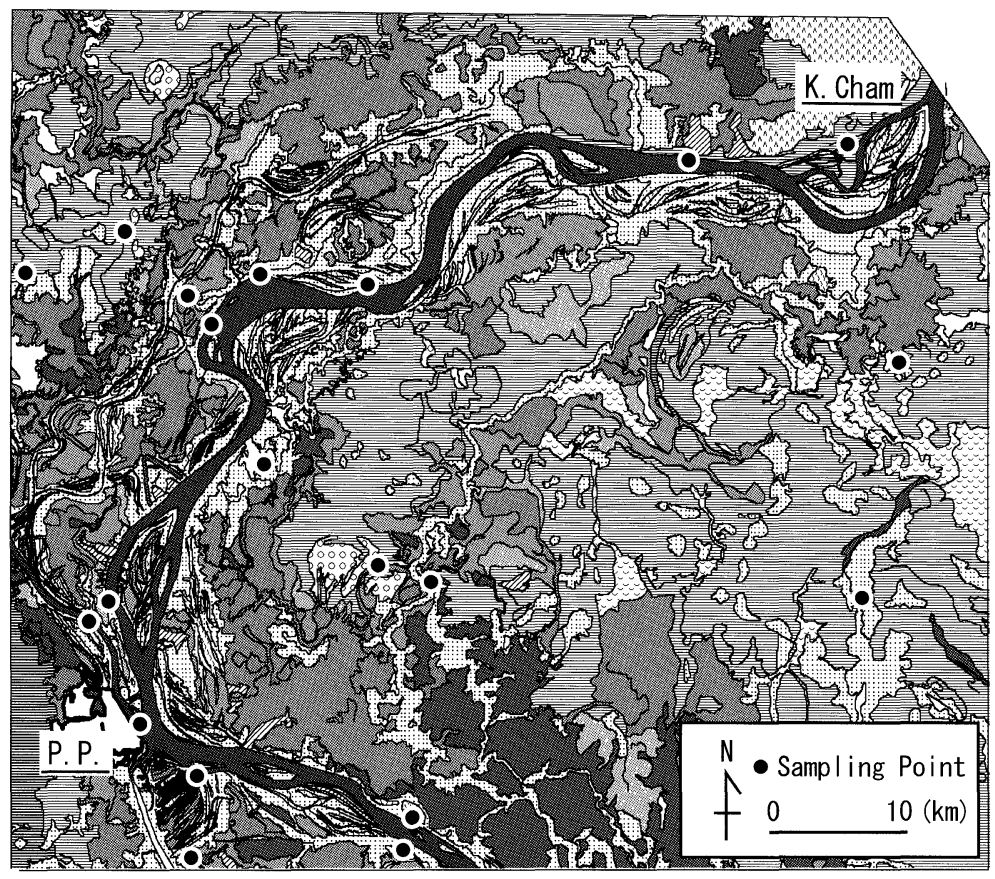

Figure 5. Land classification map of zone A. The legend is the same as in Figure 2.

and east of the river, and its flow is restricted by terraces near the $40 \mathrm{~km}$ point from $\mathrm{PP}$, and in this area, the Tonle Sap River diverges and joins several times at 10-20 km intervals. From 105 to $150 \mathrm{~km}$ above PP, near Tonle Sap Lake, the main channel is divided into many smaller channels.

\section{Floodplain characteristics}

Zone A (Figure 5): The floodplains in this zone are slightly higher than those in the other zones. Huge natural levees occur along the undercut banks of the river, and clear point bars on the slip-off banks. Natural levees $0.5-2.0 \mathrm{~km}$ wide and 6-7 $\mathrm{m}$ high have developed successively along the channels. The side slopes of the natural levees are very gentle. Surface sediments of the natural levees consist of well-sorted dark brownish fine sand to silt to a depth of several meters, similar to those in zones B and C. The natural levees are eroded evenly off the top in most of the zone. According to the local people, the annual lateral erosion rate is 15 to $20 \mathrm{~m}$. Point bars and swales are easily distinguished in aerial photographs and in the field, and the altitudinal difference between them is up to $4 \mathrm{~m}$.
The top $0.7-0.8 \mathrm{~m}$ of the floodplain bar sediments consist mainly of dark brownish silt, with a dark grayish sand layer below. Point bars have two or three cut-off patterns of progression in this zone.

In addition, two small tributaries diverge from the Mekong River in this zone. They also have successively developed natural levees and point bars that match the scale of these tributaries and few cut-off patterns are seen. Natural levees along the tributaries have similar silty surface sediment to those along the Mekong River. Except for these tributaries, abandoned channels are rarely identified. Furthermore, there are few colmatages in this zone.

Zone B (Figure 6): The landforms along profile a-a' (Figures 4 and 6) are in the order terrace, back marsh of the Mekong River (Back Marsh II), natural levees of the Mekong Riverback marsh between the Mekong River and the Bassac River (Back Marsh I), natural levees and colmatages of the Bassac River, back marsh of the Bassac River, flat terrace, and finally gently sloping terrace $(15 / 10,000)$. Profile a-a' also shows that the back marsh in this zone slopes quite gently from the lower part of the Mekong 


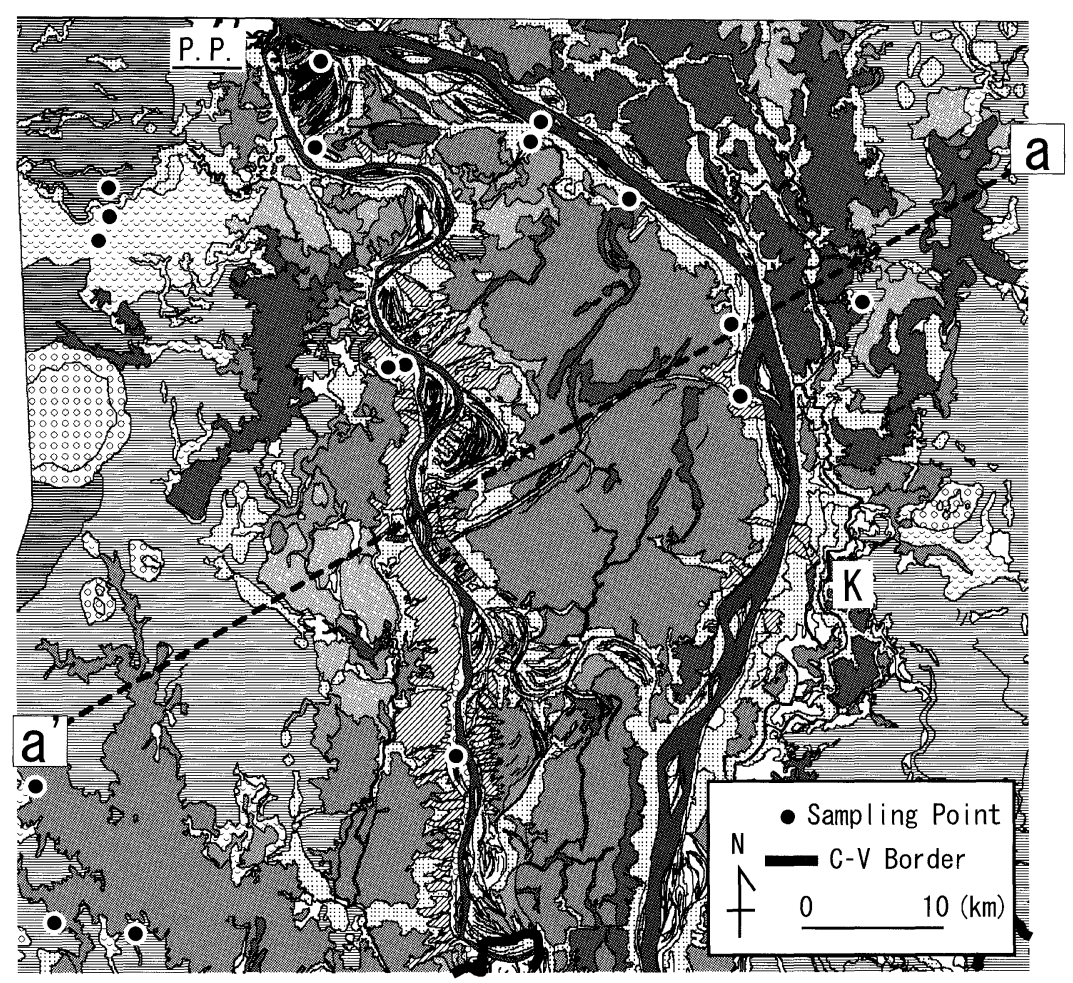

Figure 6. Land classification map of zone B and C.

Many colmatages have been constructed around " $\mathrm{K}$ ". (The legend is the same as in Figure 2)

River floodplain to the upper part of the Bassac River floodplain. Back Marsh II areas are widespread on the east side of the Mekong River, which has very poor vegetation cover. In contrast, shrubs grow widely in Back Marsh I, between the Mekong River and the Bassac River.

Natural levees are well developed along the right bank of the Mekong River compared with the left bank. The natural levees on the right bank are approximately $2.0 \mathrm{~km}$ wide. In contrast, although natural levees on the left bank are well developed in some places, they are only $0.5 \mathrm{~km}$ wide in the middle part of the zone. In the southern part, natural levees are not well developed, compared with further upstream. The surface layer of the natural levees consists of thick dark brownish silt at least $6 \mathrm{~m}$ thick, similar to that in zone A. This zone has no clear point bars. Surface sediments of holms are coarse to medium sand.

Small tributaries of the Mekong River, which diverged from the Mekong River in zone A, flow into Back Marsh II. Abandoned river channels are rarely identified in this zone, except for one between the Mekong River and the Bassac River. Furthermore, there are a few colmatages (see Figure 6) near the monadnock in the middle part of zone $\mathrm{B}$.

Zone C (Figure 6): This zone has many point bars. The pattern of point bars and swales is quite uniform, and floodplain bars are narrower than those in zone A. Although the riverbed gradient of the Bassac River in zone $\mathrm{C}$ is similar to that of the Mekong River in zones A and B, the Bassac River in this area is extremely meandering. Natural levees, about $1 \mathrm{~km}$ wide and about 4-5 $\mathrm{m}$ in height above Back Marsh I, have developed along the undercut banks of the meanders.

Moreover, many colmatages have been constructed on the back side of the natural levees in this zone. Surface geological samples were collected at two points on a colmatage $40 \mathrm{~km}$ from $\mathrm{PP}$ on the west side of the Bassac River, one near the Bassac River, and the other $1.2 \mathrm{~km}$ inside from Bassac River along a colmatage ditch. The colmatage sediments are dark brownish fine 
sand to silt $1.4 \mathrm{~m}$ thick, similar to the natural levee deposits. However, the colmatages are unevenly distributed. In the area $25-55 \mathrm{~km}$ from PP, many colmatages have been constructed at right angles to the slip-off slopes of the point bars. In contrast, small colmatages have been constructed in the back marsh area along the undercut slopes. In the area 55-80 km downstream PP, well-developed colmatages are distributed widely, while between $80 \mathrm{~km}$ downstream PP and the $\mathrm{C}-\mathrm{V}$ border, colmatages are rare.

Zone D (Figure 7): The channel geometry in

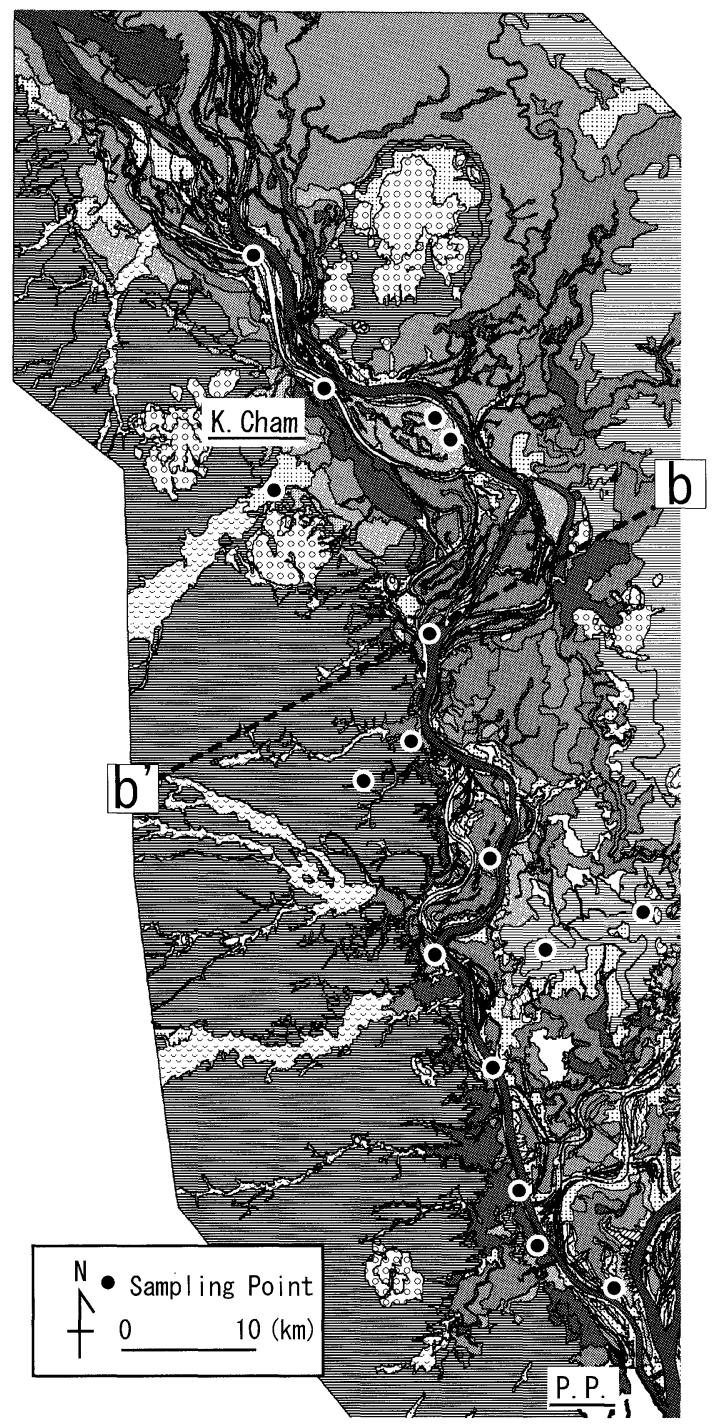

Figure 7. Land classification map of zone D. (The legend is the same as in Figure 2) this area is constrained by the terraces developed on both sides. The landforms along profile b- $\mathrm{b}^{\prime}$ (Figures 4 and 7) are in the order escarpment of mountain foothills, terrace, monadnock, back marsh on the left side of the Tonle Sap River, natural levees, multiple channels and towheads, natural levees, back marsh, and finally terrace. Terraces are developed close to the right bank of the Tonle Sap River. The floodplains around PP are about $12 \mathrm{~m}$ a.s.l., the Tonle Sap River surface is 5-10 $\mathrm{m}$ a.s.l., and the lacustrine lowlands around Tonle Sap Lake are 7-10 m a.s.l. (Figure 4).

River bank sediments of the Tonle Sap River change from coarse to fine sand near PP to clay near the Tonle Sap Lake. Natural levees about $0.5 \mathrm{~km}$ wide and about $5 \mathrm{~m}$ wide are well developed from PP to $20 \mathrm{~km}$ upstream. Upstream from the 20 -km point, however, natural levees are fragmentary, and they are less than $0.2 \mathrm{~km}$ wide.

\section{Discussion and Conclusion}

In zone $\mathrm{A}$, the several cut-off patterns of point bars (Figure 5) indicate that the flow in the main channel of the Mekong River has changed frequently and much rapidly, and many sediments have been transported from the Mekong River to this zone. However, the channel forms of the tributaries and the monotonous pattern of point bar development suggest that the flow paths and discharge of the tributaries have not varied very much during point bar formation.

Although the riverbed gradient in zone $\mathrm{B}$ is similar to that in zone A, marshy areas are widespread in this zone, indicating that minimal amounts of sediment have been transported into this zone. Taking into account the patterns of development of natural levees in the southern part of the zone and the findings of Lap et al. (2000), who reported that a mangrove marsh is present along the Mekong River in Vietnam, this zone is considered to be transitional from a fluvial dominated to a marine dominated area.

In zone $\mathrm{C}$, the development patterns of point bars and the many colmatages suggest that the rate of lateral meander development in this zone is very stable, and probably much sediment has been transported from the river into this area. The cause of these differences from zone $\mathrm{B}$ is 
unknown. Because colmatages are formed artificially by diverting water for irrigation from a main channel into a back marsh, sediments of the colmatages are considered to have been brought mainly from the Bassac River. Therefore, the extent of the development of colmatages implies the amount of sediment in each zone. The development patterns of colmatages in this zone may reflect differences in the sedimentary environment. Further study should show how this zone has been formed by considering the patterns of development of the colmatages and point bars.

Zone D has more distinctive floodplain landforms than the other zones, perhaps caused by the annual cycle of normal and reverse current flow. The grain size distribution of the surface sediments indicates that they derive in large part from the Mekong River.

In summary, the characteristics of the floodplains and their formation processes differ among the four zones. The main part of the Mekong River sediment is deposited in zone A, and the other sediment is deposited in the other zones. Although the main channel of the Mekong River is in zone B, less sediment is deposited there. In zone $\mathrm{D}$, most of the sediment has been transported from the Mekong River and deposited near PP. These facts imply that much water containing much sediment flows into the Tonle Sap River and Bassac River in the rainy season (when the discharge of Mekong River is high). In contrast, in the dry season (when discharge is low) water containing less sediment is transported into zone B of the Mekong River from zone A and from the Tonle Sap River. The results of this study will help further studies on the floodplain structures and point bar formation in this study area.

(Received 31 May 2006) (Accepted 24 January 2007)

\section{References}

Andy, J., Jorge, R., Andy, N., Andrew, F., and Mark, M. 2004. Practical use of SRTM data in the tropicsComparisons with digital elevation models generated from cartographic data. Centro Internacional de Agricultura Tropical Working Document 198, http://srtm.csi.cgiar.org/(2006.12.14).
Bernhard, R., Michael, E., Achim, R., and Richard, B. 2003. The suttle rader topography mission-A new class of digital elevation models acquired by spaceborne rader. Photogrammetry \& Remotesensing 57: 241-262.

Furukawa, H., and Takaya, Y. 1987. Topography and soil of coastal lowlands in Southeast Asia. Pedologist 31: 146-153. (J)

Haruyama, S., and Ohya, M. 1990. La caracteristique de la nature et le development de l'agriculture du basin du Mekong. J. JAICAF 13(2): 27-43. (JF)

Kubo, S. 2003. Geomorphologic features and subsurface geology of the Lower Mekong plain around Phnom Penh City. Proceedings of the General Meeting of the Association of Japanese Geographers, 63: 107. (J)

Kubo, S. 2006. Geomorphological features, flood characters, land-use and water-use in the lower Mekong plain in Cambodia. Gakujutsu Kenkyu, School of Education, Waseda Univ. 54: 1-9. (J)

Lap, N. V., Ta, T. K. O., and Tateishi, M. 2000. Late Holocene depositional environments and coastal evolution of the Mekong River Delta, Southern Vietnam. J. Asian Earth Sci. 18: 427-439.

Lee, M. A. 2001. Holocene monsoon changes inferred from lake sediment pollen and carbonate records, northeastern Cambodia. Quat. Res. 56: 390-400.

Mekong River Commission, and Ministry of Public Work and Transport of Cambodia 1999. Hydrographic atlas Mekong River in Cambodia. Mekong River Commission. and Ministry of Public Work and Transport of Cambodia.

Mekong River Commission and Ministry of Transport of Vietnam 1998. Hydrographic atlas Mekong River in Vietnam. Mekong River Commission and Ministry of Transport of Vietnam.

Ohya, M., Maruyama, Y., Umitsu, M., Haruyama, S., Hirai, Y., Kumaki, Y., Nagasawa, R., Sugiura, M., Kubo, S., Iwahashi, J., Hasegawa, S., and Ohkura., H. 2002. The study, creation and utilization of a geomorphologic land classification map. Tokyo: Kokon Shoin. (J)

Okawara, M., and Tsukawaki, S. 2002. Composition and provenance of clay minerals in the northern part of Lake Tonle Sap, Cambodia. J. Geogr. 111: 341-359.

Penny, D., Cook, G., and Im, S. S. 2005. Long-term rates of sediment accumulation in the Tonle Sap, Cambodia: A threat to ecosystem health? J. $P a-$ leolimnol. 33: 95-104.

Russ, J. C. 1995. The image processing handbook. Tokyo. CRC Press.

Ta, T. K. O., Nguyen, V. L., and Tateishi, M. 2002. Sediment facies and late Holocene progradation of the 
Mekong River Delta in Bentre Province, southern Vietnam: An example of evolution from a tidedominated to a tide- and wave-dominated delta. Sed. Geol. 152: 313-326.

Takaya, Y. 1974. A physiographic classification of rice land in the Mekong Delta. South East Asian Studies 12: 135-142.

Takaya, Y. 1975. Rice cropping pattern in southern Asian Delta. South East Asian Studies 13: 256281.

Tamura, T. Saito, Y., Sieng, S., and Tsukamaki S. 2005. Depositional facies and radiocarbon ages of the KS core from the Mekong River lowland near Phnom Penh. In Proceedings of CambodiaJapan Geoscience Meeting 2005, Japan Geoscience Union (CD-ROM), ed. Japan Geoscience Union, Q061-P006. Tokyo: Japan Geoscience
Union. (J)

Tanabe, S., Hori, K., and Saito, Y. 2003. Delta evolution model inferred from the Holocene Mekong Delta, southern Vietnam. SEPM Special Publication 76: 175-188.

The Ministry of Public Works and Transport, Kingdom of Cambodia, and Japan International Cooperation Agency. 1999. Cambodia reconnaissance survey digital data. Phnom Penh: Kingdom of Cambodia and JICA.

Toda, O., Higuchi, K., and Munemura, H. 2005. History and prospects of colmatage system in Cambodia. J. JSIDRE 73: 31-34. (J)

$(\mathrm{J})$ : written in Japanese

(JF): written in Japanese with French abstract 